\title{
Antigenic Analysis of Asian Aquatic Birnavirus Isolates Using Monoclonal Antibodies
}

\author{
V. LiPIPUn ${ }^{* 1,5}$, P. Caswell-Reno*1, Y.-L. Hsu*2, J.-L. Wu*2, M.-C. TunG*3, \\ P. W. Reno*1, W. WATtANAVIJARN ${ }^{* 4}$ and B. L. NiCHOLSON ${ }^{* 1}$ \\ ${ }^{* 1}$ Department of Microbiology and Center for Marine Studies, University of Maine, \\ Orono, Maine, 04469, USA \\ *2 Institute of Zoology, Academia Sinica, Taipei, Taiwan, Republic of China \\ ${ }^{*}$ National Pingtung Institute of Agriculture, Pingtung, Taiwan, Republic of China \\ ${ }^{*}$ Faculty of Veterinary Science, Chulalongkorn University, Bangkok, Thailand
}

(Received March 23, 1989)

\begin{abstract}
A panel of monoclonal antibodies (MAb) was used in an immunodot assay to investigate the antigenic relationships of a variety of aquatic birnaviruses from Asia. All of the Asian birnaviruses tested shared a serogroup-specific epitope with related viruses from North America and Europe. Six viruses from Taiwan were identical in MAb reaction patterns to European eel virus (EEV) and differed from the European Ab virus only by the presence of a single epitope. A single isolate from Thailand was identical to the European $\mathrm{Sp}$ virus. Ten viruses from Taiwan exhibited a variety of MAb reaction patterns that were distinct from those previously reported for the nine known serotypes of North America and Europe.
\end{abstract}

The aquatic birnaviruses are the largest and most diverse group of viruses in the family Birnaviridae and include a variety of viruses from numerous species of fish and marine molluscs worldwide (Bovo et al., 1984; DoBos et al., 1979; HedRICK et al., 1986; HiLl, 1976; SCHUTZ et al., 1984; SonSTEGAARD et al., 1972; STEPHENS et al., 1980; UNDERWOOD et al., 1977; Wolf and MANN, 1980). Some of these viruses are the etiological agents of diseases in a number of important fish species used in fish farming and aquaculture such as infectious pancreatic necrosis (IPN) in salmonids and branchionephritis in eels (SANO, 1976; SANO et al., 1981; Wolf et al., 1960). Serological studies have demonstrated that most aquatic birnaviruses are antigenically related but significant antigenic differences exist among the numerous isolates. On the basis of differences in reciprocal cross neutralization titers of polyclonal rabbit antisera with selected virus isolates three serotypes designated VR299, $\mathrm{Sp}$, and $\mathrm{Ab}$ have been identified (MACDonald

*5 Present address: Department of Microbiology, Faculty of Pharmaceutical Sciences, Chulalongkorn University, Bangkok, Thailand. and Gower, 1981; Окамото et al., 1983). In similar studies of a large number of birnavirus isolates worldwide, HILL and WAY (1983) confirmed these three serotypesalthough changing the designation of serotype VR299 to West Buxton (WB). In addition, these investigators demonstrated six additional serotypes which together with the original three represent a single major serogroup (Serogroup A) and four individual isolates that represent a second serogroup (Serogroup B).

Although there are no apparent correlations between the aquatic birnavirus serotypes and specific diseases or host species, individual serotypes of Serogroup A are generally restricted to one or more broad geographical areas. West Buxton (WB) is the predominant, if not sole, serotype detected in the United States whereas there are four serotypes found only in Canada (Canada 1, Canada 2, Canada 3, and Jasper) and four serotypes in Europe ( $\mathrm{Sp}, \mathrm{Ab}$, Hecht, and Tellina). Aquatic birnaviruses from Asia have not been as well studied, although most isolates to date have been reported to belong to either the WB or Ab serotypes with the majority of isolates included in the latter 
(Hedrick et al., 1985; Lipipun et al., 1988). Whereas $\mathrm{Ab}$ serotype viruses from Asia have been isolated from a variety of fish and shellfish species, most WB serotype viruses from Asia have been limited to salmonids.

Monoclonal antibodies (MAb) have been developed and used in several investigations for antigenic characterization and improved diagnosis of the aquatic birnaviruses (CASWELLReNo et al., 1986; Wolski et al., 1986). However, most of these serological studies using MAbs have concentrated on viruses from North America and Europe. Little information is available about the detailed antigenic characteristics of individual birnavirus isolates from Asia with the exception of one report demonstrating that EEV virus (LIPIPUN et al., 1988), an Asian birnavirus isolated from eels and belonging to the $\mathrm{Ab}$ serotype, could be distinguished from the $\mathrm{Ab}$ type strain by the presence of at least one epitope recognized by one MAb.

Recently, a panel of MAbs has been developed and used in a simple immunodot assay for rapid screening as well as serotyping viruses of Serogroup A (CASWell-ReNo et al., 1989). In this report we describe the use of this panel of MAbs to investigate the antigenic relationships of a variety of aquatic birnaviruses from Asia.

\section{Materials and Methods}

Viruses: The viruses used and their source of origin are listed in Table 1. The isolation and propagation of EEV and E1S viruses have been described previously (SANO et al., 1981; Wu et al., 1987). The other viruses used in this study were isolated by workers in several laboratories over a period of severaly ears as part of fish disease research and/or diagnostic programs. MFK, TF, CV-1, and PV viruses were isolated by Y.-L.H. and J.-L.W. in northern and central Taiwan; CV-HB-1 and CV-TS-1 were isolated in northern Taiwan by Dr. C.-F. Lo, Fu-Jen University, Taipei, R.O.C.; DPL virus was isolated by W.W. in Thailand; and the remaining viruses were isolated by M.-C.T. in southern Taiwan. For this study, all viruses were propagated in CHSE-214 cell cultures at $20 \mathrm{C}$ and cloned by end-point dilution as pre- viously described (CASWELL-RENo et al., 1986). Monoclonal antibodies (MAb): Hybridoma development and characterization of the MAbs (AS-1, W1, W2, W3, W4, W5, E1, E2, E3, E5 and E6) used in this study have been described previously (CASWELL-RENO et al., 1986; LIPIPUN et al., 1989; CASWELL-RENO et al., 1989). The source of MAbs for this investigation were supernatant fluids from hybridoma cultures propagated at 37C in Dublecco's modified Eagle's Minimum Essential Medium (MEM) with D-glucose $(4.5 \mathrm{mg} / \mathrm{ml})$, NCTC 109 medium $(10 \%)$, bovine pancreatic insulin $(0.2 \mathrm{unts} / \mathrm{m} l)$, oxaloacetic acid (1 mM), pyruvic acid $(0.45 \mathrm{~mm})$, and fetal bovine serum (15\%).

Immunodot test: The enzyme immunodot test was performed as outlined previously (LIPIPUN et al., 1988; CASWELL-RENO et al., 1989). Briefly, two $\mu l$ aliquots of infected cell culture supernatants containing virus at a minimum titer of $10^{4} \mathrm{TCID}_{50} / \mu l$ were "dotted" onto nitrocellulose strips (Bio-Rad Laboratories, Richmond, CA) and air dried at roomtemperature. After washing four times with tris-buffered saline (TBS), $\mathrm{pH} 7.4$, the remaining nonspecific protein binding sites were blocked with $3 \%(\mathrm{w} / \mathrm{v})$ bovine serum albumin (BSA) and $10 \%(\mathrm{v} / \mathrm{v})$ calf serum (CS). Individual strips were then incubated for $3 \mathrm{~h}$ at room temperature in each MAb at concentrations atleast two times the minimum previously determined to give positive results with homologous virus. After washing and blocking as above, the strips were incubated for $2 \mathrm{~h}$ with goat anti-mouse immunoglobulin conjugated with horseradish peroxidase, washed, and incubated for $10 \mathrm{~min}$ in substrate $(0.5 \mathrm{mg}$ of 4-chloronapthol and 10 $\mu l$ of $3 \% \mathrm{H}_{2} \mathrm{O}_{2}$ in $1 \mathrm{~m} l \mathrm{TBS}$ ). A positive reaction was indicated by a visible purple color.

\section{Results}

A panel of 11 monoclonal antibodies (MAbs), including a group reactive as well as serotype or strain specific MAbs, has been developed for the aquatic birnaviruses and used in a variety of serological assays for studying antigenic characteristics, general virus screening, and serotyping (CASWELl-ReNo et al., 1986; LIPIPUN et al., 1988; CASWELl-ReNo et al., 1989). 
Table 1. Asian aquatic birnavirusesisolates

\begin{tabular}{|c|c|c|c|c|}
\hline Virus & Country & \multicolumn{3}{|c|}{ Host } \\
\hline $\begin{array}{c}\text { European eel virus } \\
\text { (EEV) }\end{array}$ & Japan & \multicolumn{3}{|c|}{ Eel (Anguilla anguilla $\mathrm{L}$. ) } \\
\hline E1S & Taiwan, R.O.C. & \multicolumn{3}{|c|}{ " (Anguila japonica) } \\
\hline 288 & Taiwan, R.O.C. & $"$ & $"$ & $"$ \\
\hline 321 & Taiwan, R.O.C. & " & " & " \\
\hline 339 & Taiwan, R.O.C. & " & " & " \\
\hline 409 & Taiwan, R.O.C. & " & " & " \\
\hline 553 & Taiwan, R.O.C. & " & " & " \\
\hline 3371 & Taiwan, R.O.C. & " & " & " \\
\hline 3372 & Taiwan, R.O.C. & " & " & " \\
\hline 3748 & Taiwan, R.O.C. & " & " & " \\
\hline 6194 & Taiwan, R.O.C. & " & $"$ & $" \prime$ \\
\hline MFK & Taiwan, R.O.C. & \multicolumn{3}{|c|}{ Milkfish (Chanos chanos) } \\
\hline $\mathrm{TF}$ & Taiwan, R.O.C. & \multicolumn{3}{|c|}{ Trout (Oncorhynchus mykiss) } \\
\hline CV-1 & Taiwan, R.O.C. & \multicolumn{3}{|c|}{ Clam (Meretrix lusoria) } \\
\hline CV-HB-1 & Taiwan, R.O.C. & Clam & " & " \\
\hline CV-TS-1 & Taiwan, R.O.C. & Clam & " & $" \prime$ \\
\hline PV & Taiwan, R.O.C. & \multicolumn{3}{|c|}{ Perch Lateolabrax japonicus) } \\
\hline DPL & Thailand & \multicolumn{3}{|c|}{ Snakehead (Ophicephalus striatus) } \\
\hline
\end{tabular}

In this report these MAbs were used in an immunodot assay to compare the antigenic relationships of a variety of aquatic birnavirus isolates from Asia. These viruses and the species from which they were isolated are listed in Table 1. The cross-reactivity of each MAb with these viruses is shown in Fig. 1. MAb AS1, which previously has been shown to react with all Serogroup A birnaviruses tested, and MAb E1 reacted with all 18 viruses in this study. Three MAbs (W1, W2, and E2), which recognize epitopes occurring on all $\mathrm{Ab}$ serotype viruses tested in previous studies, reacted with EEV and all virus isolates from Taiwan but did not react with isolate DPL from Thailand. Similarly, MAb E5, which in other studies reacted with all isolates tested from North America and Europe, reacted with most of these isolates from Asia but, interestingly, did not react with two isolates from eels in Taiwan. Also, MAb E6, which reacts with all $\mathrm{Ab}$ serotype viruses, only reacted with eight viruses here. The epitope defined by MAb E3, which distinguishes EEV from the $\mathrm{Ab}$ strain of IPNV, was detected on nine of the viruses in this group. MAb W3 reacted with only five of these viruses and MAbs W4 and W5 failed to react with any of the Asian isolates.

\section{MONOCLONAL ANTIBODY (MAB)}

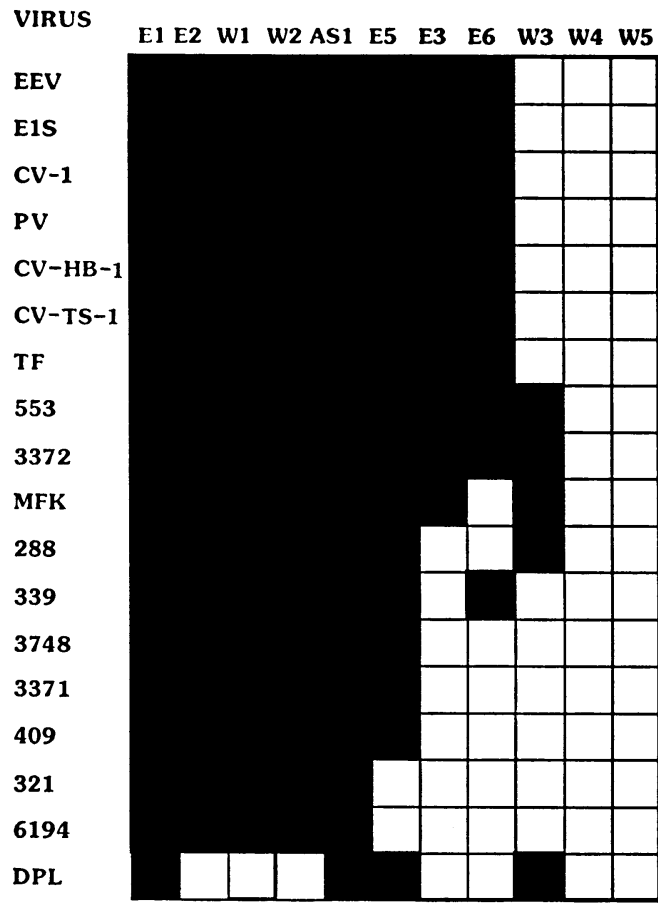

Fig. 1. Reaction of monoclonal antibodies (MAb) with Asian birnaviruses in immunodot assay. $\square=$ positive reaction, $\square=$ negative reaction 
Overall, this panel of MAbs displayed eight distinct patterns of cross reactions with the 18 viruses.

\section{Discussion}

The availability of a number of new birnagrus isolates from a variety of fish and shellfish species in Asia provided an opportunity to use a panel of recently developed monoclonal antibodies (MAb) (CASWELL-RENO et al., 1986; LIPIPUN et al., 1988; CASWELL-RENo et al., 1989) to investigate the antigenic relationships of a group of relatively uncharacterized birnaviruses from Asia, a geographical area where little is known about the detailed antigenic characteristics of such indigenous viruses. Previous studies using polyclonal antisera have been shown that most aquatic birnaviruses from Asia, particularly those from non-salmonid species, belong to the Ab serotype of Serogroup $A$, one of four serotypes occurring in Europe. However, it was not known whether all of these isolates were identical to each other or to the European $\mathrm{Ab}$ virus in antigenic characteristics except for a recent report showing that EEV, an Asian Ab serotype virus, differs from the European $A b$ type strain virus in at least one epitope (LIPIPUN et al., 1988).

All of the viruses included in this study reacted with MAb AS1 which also has been shown to react with all Serogroup A aquatic birnaviruses tested from North America and Europe (CASWell-Reno et al., 1989). These results support the view that this MAb recognizes a Serogroup A reactive epitope. Furthermore, the fact that this epitope apparently has been conserved among all the aquatic birnaviruses worldwide suggests that it serves a relatively important structural or functional role and is, therefore, a prospective target for general diagnostic assays and vaccine development.

The data presented here show that five of these new isolates from several species including eel, perch, trout, and clams were idential to EEV in MAb reaction patterns. We have previously shown (CASWELL-RENO, ei al., 1989) that EEV and several of these viruses differ from the $A b$ serotype strain only in one epitope
(E3) described by this panel of MAbs. Therefore, it appears that many of the aquatic birnaviruses in Asia are closely related serologically to members of one of the major serotypes found in Europe. All but one of the other isolates examined in this study also reacted with MAbs E2, W1 and W2 which is characteristic of $\mathrm{Ab}$ serotype viruses; however, the reaction patterns of 10 of these isolates with the entire panel of MAbs varied and were not consistent with known $\mathrm{Ab}$ serotype viruses nor with those of any of the other eight serotypes (CASWell-Reno et al., 1989). Particularly interesting was the fact that two viruses did not react with $\mathrm{MAb}$ E5 which reacts with all aquatic birnaviruses tested from North America and Europe indicating that some Asian viruses are antigenically distinct in that they lack this particular epitope which has been highly conserved among similar viruses occurring on other continents. Whether these viruses actually are members of the $\mathrm{Ab}$ serotype and the current criteria using MAbs for classifying isolates $a \mathrm{Ab}$ type must be revised or whether they represent one or more new serotypes remains to be determined.

The DPL virus isolate from snakehead fish in Thailand appeared significantly different from the other isolates from Taiwan and Japan. In fact, by $\mathrm{MAb}$ reaction patterns described by CASWELL-RENO et al. (1989), this virus appeared from the data in this study to belong to the Sp serotype. Recently, another birnavirus isolate belonging to the $\mathrm{Sp}$ serotype was reported from snakehead fish in Thailand (Wattanavijarn et al., 1988). Previously, the only report of an Sp serotype virus in Asia was from imported rainbow trout $(O$. mykiss) in the Peoples Republic of China (Yulin and ZhengyiU, 1987). Also, HedRICK et al. (1986) have described a birnavirus isolated from sand goby in Thailand that appears significantly different in serology and biochemical characteristics from other aquatic birnaviruses, including Sp. Most aquatic birnavirus isolates from Asia have come from Japan, Korea, and Taiwan. Because the three recent isolates from species indigenous to Thailand exhibit significant antigenic diffecences from these other viruses, it would be interesting to investigate 
the antigenic relationships of additional birnaviruses from Thailand as well as viruses from other countries in Southeast Asia.

Overall, based on the different patterns of cross-reactivity with this panel of MAbs, at least eight different strains of aquatic birnaviruses were identified in this group of new isolates. These isolates were obtained from several species from a variety of geographical sites over a period of several years. No apparent correlations were detected between individual antigenic strains and host species or geographic origin.

In summary, this investigation has demonstrated that all of the Asian aquatic birnaviruses examined share a serogroup specific epitope with related viruses from North America and Europe and that six of these new Asian viruses were identical to EEV and could be distinguished from the European $\mathrm{Ab}$ virus only by the presence of a single epitope recognized by MAb E3. One isolate from Thailand appeared similar to the European Sp strain and 10 viruses gave varying reaction patterns that were distinct from those previously reported for the nine known serotypes of North America and Europe.

\section{Acknowledgments}

This research was supported by grants from the National Oceanic and Atmospheric Administration (NOAA) University of Maine Sea Grant College Program (No. R/FMD-177), the National Science Foundation (No. INT810447), the Maine Agriculture Experiment Station, and the University of Maine Center for Marine Studies. Publication No. 1394 of the Maine Agriculture Experiment Station.

\section{References}

Bovo, G., G. Ceschia, G. Giorgetti and M. VANeLLI (1984): Isolation of an IPN-like virus from adult kuruma shrimp (Penaeus japonicus). Bulletin of the European Association of Fish Pathologists, 4, 21.

Caswell-Reno, P., P. W. Reno and B. L. Nicholson (1986): Monoclonal antibodies to infectious pancreatic necrosis virus: analysis of viral epitopes and comparison of different isolates. Journal of General
Virology, 67, 2193-2205.

Caswell-Reno, P., V. Lipipun, P. W. Reno, and B. L. Nicholson (1989): Utilization of a group reactive and other monoclonal antibodies for identification and presumptive serotyping of aquatic birnaviruses. Journal of Clinical Microbiology, in press.

Dobos, P., B. J. Hill, R. Hallet, D. T. C. Kells, H. Becht and D. Teninges (1979): Biophysical and biochemical chracterization of five animal viruses with bisegmented double-stranded RNA genomes. Journal of Virology, 32, 593-605.

Hedrick, R. P., Eaton, W. D., Fryer, J. L., Hah, Y. C., PARK, J. W., and Hong, S. W. (1985): Biochemical and serological properties of birnaviruses isolated from fish in Korea. Fish Pathology, 20, 463-468.

Hedrick, R. P., W. D. Eaton, J. L. Fryer, W. G. Groberg and S. Boonyaratapalin (1986): Characteristics of a birnavirus isolated from cultured sand goby Oxyeleotris marmoratus. Diseases of Aquatic Organisms, 1, 219-225.

HiLl, B. J. (1976): Molluscan viruses: their occurrence, culture and relationship. in Proceedings of the 1st International Colloquim on Invertebrate Pathology, pp. 25-29. Queens University Press, Kingston, Can.

HiLl, B. J. and K. WAY (1983): Serological classification of fish and shellfish birnaviruses. (abstract). First International Conference of the European Association of Pathology, Plymouth, England.

Lipipun, V., P. Caswell-Reno, P. Reno, and B. Nicholson (1988): Enzyme immunoassay utilizing monoclonal antibodies for identification of European eel virus (EEV), an aquatic birnavirus. in "Immunological Approaches to Coastal, Estaurine, and Oceanographic Questions-Lecture Notes on Coastal and Estaurine Studies-\#25" (C. YeNTSCH, F. Mague, and Ph. Horan, eds.), pp. 312-317, Springer-Verlag.

MacDonald, R. D. and D. A. Gower (1981): Genomic and phenotypic divergence among three serotypes of aquatic birnaviruses (infectious pancreatic necrosis virus). Virology, 115, 187-195.

Nicholson, B. L. and P. Caswell (1982): Enzymelinked immunosorbent assay for identification of infectious pancreatic necrosis virus. Jornal of Clinical Microbiology, 16, 469-472.

Okamoto, N., T. SANo, R. P. Hedrick and J. L. FrYer (1983): Antigenic relationships of selected strains of infectious pancreatic necrosis virus (IPNV) and eel virus European (EVE). Journal of Fish Diseases, 6, 19-25.

SANO, T. (1976): Viral diseases of cultured fishes in Japan. Fish Pathology, 10, 221-226. 
Sano, T., N. Okamoto and T. Nishimura (1981): A new viral epizootic of Anguilla japonica Temminck and Schlegel. Journal of Fish Diseases, 4, 127-139.

Schutz, M., E. B. May, J. N. Kraeuter and F. M. HETRICK (1984): Isolation of infectious pancreatic necrosis virus from an epizootic occurring in cultured striped bass, Morone saxatilis (Walbaum). Journal of Fish Diseases, 7, 505-507.

SonstegaARd, R. A., L. A. McDermott and K. S. SONSTEGAARD (1972): Isolation of infectious pancreatic necrosis virus from white suckers (Catastomus commersoni). Nature, 236, 174-175.

Stephens, E. B., M. W. Newman, A. L. Zachary and F. M. Hetrick (1980): A viral aetiology for the annual spring epizootics of Atlantic menhaden, Brevoortia tyrannus (LATROBE) in Checsapeake Bay. Journal of Fish Diseases, 3, 387-398.

UNDerwood, B. O., C. J. SMAle, F. Brown and B. J. Hill (1977): Relationships of a virus from Tellina tenuis to infectious pancreatic necrosis virus. Journal of General Virology, 36, 93-109.

WattanavijaRn, W., C. Torchy, J. TANGTronpipos and P. DEKINKELN (1988). Isolation of a birnavirus belonging to Sp serotype from South East Asia fishes. Bulletin of the European Association of Fish Pathologists, 8, 106-108.

Wolf, K. and J. A. MANN (1980): Poikilothermic vertebrate cell lines and viruses. A current listing for species. In Vitro, 16, 168-169.

Wolf, K., S. E. Snieszko, C. E. Dunbar and E. PYLE (1960): Virus nature of infectious pancreatic necrosis in trout. Proceedings of the Society for Experimental Biology and Medicine, 104, 105-108.

Wolski, S. C., B.S. Roberson and F. M. Hetrick (1986): Monoclonal antibodies to the Sp strain of infectious pancreatic necrosis virus. Veterinary Immunology and Immunopathology, 12, 373-381.

Wu, J. L., C. Y. Chang, and Y.L. Hsu (1987): Characteristics of an infectious pancreatic necrosislike virus isolated from Japanese eel (Anguilla japonica). Bulletin of the Institute of Zoology, Academica Sinica, Taiwan, R.O.C., 26, 201-214.

Yulin, J. and L. ZHeNGyiu (1987): Isolation of IPN virus from imported rainbow trout (Salmo gairdneri) in the Peoples Republic of China. Journal of Applied Ichthyology, 3, 131-132. 